\title{
Role of Grama Panchayat: A Special Reference in Uttar Kannada District
}

\author{
Assistant Prof. Dr. Nasarulla M Khan \\ Department of Political Science, GFGC Ankola
}

\begin{abstract}
Panchayats have been the backbone of the Indian villages since the beginning of the recorded history. This involves micro-level planning at district, taluk and village level. The Gram Sabha has a key role in bringing about transparency in the functioning of the Gram Panchayats, in ensuring equitable distribution of benefits, in creation of community assets where these are needed and in bringing about social cohesion. Gram Sabha needs to be supplemented with other appropriate measures to ensure regular and suitable functioning of the Sabha now envisaged as an important part of the Panchayat system. A Gram Sabha is required to 'meet as many times in a year as provided in the Panchayati Raj Act of the respective States. where women Sarpanches from weaker sections may not match with those headed by men, such cases are. The District role of the Gram Sabha is, perhaps, the most important in ensuring the success of Panchayati Raj Institutions at the village level and also role of local people in conducting social audit and fixing responsibility on Panchayat functionaries will also be effectively ensured with the Gram Sabhas becoming active.
\end{abstract}

Keyword: Panchayats, Gram Sabha and Political

\section{Grama (Village) Panchayat Introduction}

The Panchayat is the Executive Committee of Gram Sabha. It is called by different names in different areas, e.g. it is named Panchayat in Andhra Pradesh, Tamil Naidu, Maharashtra and Rajasthan, the Gram Panchayat (GP) in Punjab, Bihar, Karnataka, Madhya Pradesh and the Gaon Panchayat in Assam, Gujarat, Uttar Pradesh, etc. Out of three institutions established under the Act, the GP constitutes the most effective tier of PRI. Every Gram Panchayat is a body corporate with perpetual succession, capacity to acquire, hold, transfer the property and authority to enter into contracts. It functions as a unit of local self-government with participation of people. All the villages have not Panchayats as some of them are very small. That is why some villages which are very small are clubbed to make a Panchayat. There are 2,18,116 panchayats against 5.8 lakh villages.

\subsection{Composition}

There has been wide variation in the size of population in a Panchayat. The size depends upon a number of factors, i.e. density of population, topographical conditions, historical existence and the law governing at that time. Members of the Panchayat are called Panches and are elected by Gram Sabha by secret ballot in all the States except Assam, Jammu \& Kashmir. For conducting elections, the entire Gram Sabha area is divided into territorial wards, each ward electing one Panch. Uttar Kannada District where a Gram Panchayat is constituted for a minimum of 500 persons. It has an average population of about 1550 and covers an average number of 1.12 villages. At present there are 951 Panchayats against 1073 villages. The number of Panches varies from 5-9 which was changed to 5-13.

\subsection{Reservations}

The Panchayati Raj Act of Punjab, Haryana and H.P. include provisions for reservation, in the following manner:

(i) At least $1 / 3$ seats of $\mathrm{SC} / \mathrm{ST}$,

(ii) At least 1/3 seats for women (including SC/ST women), and

(iii) 1 seat for B.Cs. where population of B.c. in Gram Sabha is more than $20 \%$. 


\section{Gram Sabha Meaning}

Panchayats have been the backbone of the Indian villages since the beginning of the recorded history. Gandhiji's dream of every village being a republic has been translated into reality with the introduction of three-tier Panchayati Raj system to enlist people's participation in rural reconstruction. 24 April 1993 is a landmark day in the history of Panchayati Raj in India as on this day the Constitution (73rd Amendment) Act, 1992 came into force to provide constitutional status to the Panchayati Raj Institutions. The Gram Sabha is defined in Section 2(16) of the Panchayati Raj Act, 1992 as a body consisting of persons registered in the electoral roll relating to a village comprised within the area of Gram Panchayat.

\section{IMPORTANCE}

In Panchayat Raj System the Gram Sabha occupies a very important place. The democratic decentralisation envisages decentralised planning. Many of the state functions have been transferred to the Panchayat Raj bodies for better and effective implementation. This involves micro-level planning at district, taluk and village level. The Gram Sabha has a key role in bringing about transparency in the functioning of the Gram Panchayats, in ensuring equitable distribution of benefits, in creatio, $n$ of community assets where these are needed and in bringing about social cohesion. It has been envisaged that Gram Sabhas shall plan and prioritize development works to be taken up in the village; approve annual plan for the Gram Panchayat; seek active participation of women, scheduled castes and scheduled tribes; ensure transparency in the working of Gram Panchayat; exercise the right to check the accounts of the Gram Panchayat, select beneficiaries under various schemes of the Central Government undertaken for rural development, and move towards full control over management of natural resources. According to the report of the Working Group on Decentralization 2002, (Department of Rural Development and Panchayat Raj, Government of Karnataka),-Every PR law gives a prominent legal position to the institution of the Gram Sabha, but in practice, this is only a formal obeisance. Often, one is told, the utopian concept of people getting together to solve their problems does not work in the cold reality of local politics and power structures. We believe that if the concept does not work, it signifies an essential failure of democracy and renders weak the entire edifice of decentralized democratic governance through Panchayat Raj Institutions that is built on this principle. To neglect the Gram Sabha is a sub-optimal development strategy. A well functioning institution of Gram Sabha could work wonders as an instrument of people's empowerment, in more ways that we may well imagine. The working group is convinced that all efforts towards effective democratic decentralization would be almost futile without making the Gram Sabha truly representative of the people, their aspirations and their management skills. Empowering Gram Sabhas will surely dilute the discretionary powers of the Gram Panchayat members and reassert the character of villages as social units; regardless of whom the individuals vote for.

\section{FunCTIONS}

Past experience of functioning of Gram Sabha in certain States in which it existed was, by and large, discouraging. Meetings were not held regularly or suggestions made by the Sabha members were ignored by the Gram Panchayat on one pretext or the other. Though there was legal provision in many states for penalising the Gram Panchayat chairperson for not convening meetings of the Sabha as prescribed, this did not prove effective. It therefore needs to be supplemented with other appropriate measures to ensure regular and suitable functioning of the Sabha now envisaged as an important part of the Panchayat system. The Gram Sabha has a variety of functions as per the' Act. They are:

1. To prepare and promote development schemes of the village;

2. To organize sanitation and drainage schemes of the village;

3. To mobilize voluntary labour and contribute in kind and cash for the community welfare programme; and

4. To assist the Panchayat in the implementation of developmental schemes pertaining to the village.

\section{Meetings of Gram SABha}

Different States have different methods of calling Gram Sabha meetings. A Gram Sabha is required to 'meet as many times in a year as provided in the Panchayati Raj Act of the respective States. Most of the States have provided for minimum two Meetings of Gram Sabha in a year, while some States have 
made provisions for 3-4 Meetings. Presence of prescribed number of Members in the Gram Sabha forms the quorum. As many as ten States have fixed one-tenth of total members of the Gram Sabha as a quorum of Gram Sabha Meetings. Some States have fixed the quorum as one-fifths of total members of Gram Sabha. However, usually no quorum is necessary for a meeting adjourned for want of quorum. The Secretary of the Gram Panchayat acts as Secretary of the Gram Sabha. He prepares the resolutions of the Gram Sabha and places these before the Gram Panchayat meeting for follow-up action.. It has been found that the Gram Sabhas are not generally held regularly because of many reasons such as lack of awareness among the people about the role and importance of the Gram Sabha, holding the Meeting with no prior notice or very short notices, lack of initiative by Pradhan/Sarpanch and Ward Members in organizing these Meetings, inter-personal! group rivalry in the village, location of Meeting and suitable timings. As a result, whenever the Meetings are held, they are adjourned due to lack of prescribed quorum. Attendance of women in these Meetings is usually nominal. The Confernce of the State Ministers of Rural Development and Panchayati Raj held in Delhi on 13th May, 1998 resolved that the Gram Sabha should be convened on a single predetermined day every quarter. In pursuance of this resolution, the Union Government advised the State Governments/Union Territory Administrations to ensure that Gram Sabhas should meet at least once in each quarter, preferably on 26th January-Republic Day, 1st May-Labour Day, 15th AugustIndependence Day and 2nd October-Gandhi Jayanti. However, no minimum quorum for Gram Sabha was fixed by the Union Government. The State Governments/Union Territory Administrations were advised to make legal provisions for the presence of women, Scheduled Castes and Scheduled Tribes in the quorum of Gram Sabha meetings.

\section{Role of Women in Gram SabHa}

Standing Committee in Urban and Rural Development No. 37, 2002 took up the issue of participation of women in the proceedings of Gram Sabha. The Committee asked the Ministry to assess the functioning of Gram Sabhas led by women Sarpanches. Further, it was asked whether any difference/ deficiency has been detected in the functioning of Gram Sabhas with women Sarpanches, the Government replied as below : "There appears to be no substantive difference in the functioning of Gram Sabhas led by women Sarpanches in comparison to that of male Sarpanches. While a few cases have come to notice where women Sarpanches from weaker sections may not match with those headed by men, such cases are, however, disappearing consequent on women Sarpanches getting trained in matters relating to their functions. On the other hand, it has been experienced that in some cases in Bihar, attendance of women was more in the Gram Sabhas led by women Sarpanches." . Further the Ministry also pointed out certain steps to activate the women Sarpanch led Gram Sabhas: ". . . To build their self-confidence, members of Panchayats, especially women Members are required to be sensitized about their role and responsibilities in developmental programmes and to encourage their participation in the decision-making process. They may be oriented with necessary skills related to conduct of meetings, budget preparation, financial management of Panchayat funds and its applications, purchase rules and inventory management, maintenance of accounts, social justice and gender issues, communication skills, leadership style and responsive administration, etc."

\section{Role OF EXeCUTIVE OfFicer IN THE Gram SABHAS}

As per the information received from the Ministry, the role of the Executive Officer in Gram Sabhas has been enumerated as below: "The role of Executive Officer, i.e. Panchayat Secretary in the Gram Sabha is to record the proceedings, to place before the Gram Sabha, income and expenditure statement and status of works undertaken by the Gram Panchayat. He also helps the Presiding Officer with regard to the provisions of Acts, Rules and instructions issued by the Government. Besides, he also gives such information as required by the Gram Sabha. In some States, Executive Officers like Deputy District Development Officer, Taluka Development Officer and village level officers attend the Gram Sabha meetings to guide the Gram Sabhas regarding different schemes/ development work and also the infrastructure facilities, which are to be taken up in the village."

\section{Functioning of Gram Sabhas}

This has to be accomplished in most of the District. The role of the Gram Sabha is, perhaps, the most important in ensuring the success of Panchayati Raj Institutions at the village level. The role of local people in conducting social audit and fixing responsibility on Panchayat functionaries will also be effectively ensured with the Gram Sabhas becoming active. It is, therefore, essential that the village 
community perceives meetings of the Gram Sabha as useful and the most important factor for this is the 'empowerment' of the Gram Sabha. The cutting edge of Panchayat Raj System is the Gram Sabha located in every revenue village. Organization of Gram Sabhas in villages helps the Panchayat in selecting the beneficiaries. The reports of the Committee of Panchayat and Tribal Development Ministers of the Schedule V States and the Committee of Chief Ministers under the Chairmanship of the Prime Minister submitted in 1997 have made following 7 points package to strengthen the role of Gram Sabha:

1. Selection of development Gram Sabha.

2. Requirement of Technical sanction for works upto Rs. 10,000 should be waived.

3. Adequate manpower support to the Gram Panchayats would need to be provided.

4. Delegate total control over such manpower to Gram Panchayats.

5. Zilla Parishad Chairpersons be made the Chairpersons of DRDAs.

6. Provide reasonable opportunity of being heard to the PRIs before suspension/ dismiss,

7. Gram Panchayat President to be made accountable only to Gram Sabha. Another important factor for the success of the Panchayati Raj system is the need for 'transparency' in the functioning of these bodies. Panchayats being closer to the people, their right to information and accessibility to the panchayats must be 'ansured. This issue was discussed in the Chief Ministers' Conference' held on 2nd August, 1997 and the Committee of Chief Ministers as well. The Ministry had written to the States. The Hon'ble Prime Minister too, in his letter to the Chief Ministers, had urged that all relevant information on development schemes taken up by the Panchayat along with the budget allocated for them should be displayed prominently in the Panchayat Office. Relevant records should be made available for inspection by members of the public. Photocopies of documents such as muster rolls, vouchers, estimates, etc. can be made available to the public on payment of a nominal fee. 'Technical manuals' may be prepared for execution of various works at the Panchayat level so that transparency is ensured.

\section{Causes of Failure of Gram Sabhas}

The causes of failure of Gram Sabha as an institution are numerous. It extends from the apathy of people to the procedural constraints and social reasons while conducting the Gram Sabha meeting. The state governments often do not give clear specification to the districts or its lower levels about the conduct of Gram Sabha meeting. Issues like time fixation, announcement of meeting place are left vague at Panchayat level. The state of Karnataka and Kerala, however, have taken a proactive role in strengthening this institution through statutory means, in order to realize the goals of rural development through democratic decentralization. Many of the concerned officers expressed their reluctance to attend Gram Sabha meeting in the village, despite the fact that their attendance was insisted upon by the government. Though a long list of activities was assigned for discussion in Gram Sabha meeting, many people are not at all aware of activities, such as health and adult education programmes in the village. The reasons for gradual decline in Gram Sabha attendance are:

1) Lack of People's Participation The structural arrangement for people's participation in the decentralized planning process through Gram Sabha at grass-root level is a non-starter in most of the areas due to official indifference and vested interests. The Adhyakshas therefore have to be trained in leadership qualities and communication skills from the district to the village level to successfully organize Gram Sabha and achieve' the desired goals of Panchayat Raj.

2) Appalling Poverty Due to poor living conditions and perennial scarcity of essential amenities like water, roads, schools and even burial grounds, a villager has no time or energy left to attend to larger community issues.

3) Attitude of Bureaucrats The lower level bureaucracy underrates the intelligence and capability of the people to offer suggestions for improvement of local administration, developmental programmes and betterment of services. They do not extend the normal courtesies of giving patient hearing to the people when they approach them with their grievances. This frustrates the people and they lose interest in the government programmes. Therefore, unless attitudinal change of the officials and elected representatives takes place, mere decentralization of administration and devolution of authority to PRIs will not elicit the faith of people in the system. 
4) Inadequacy of People's Associations and Organisation As individuals, people grumble and groan against maladministration, yet they do not organize themselves into well-knit groups to fight for their common interests. Hence, citizens' awareness associations need to be formed to safeguard the public interest. The rural poor, the women and the marginalized get an opportunity to effectively participate in making fecisions that affect their own well-being as this is an open forum. Thus, giving prime place to the Gram Sabha in the system of local governance, the Union Ministry of Rural Development has made it mandatory that in some centrally sponsored schemes, the Gram Sabha should have final authority.

5) Absence of Political Will The empowerment of Gram Sabha means dilution of powers and perks of the officials as well as non-officials alike.

Hence, only an external force could act upon the vested interest to give up self-interest in the interest of public or nation as a whole. Regularity of Meetings The State Governments have been requested to ensure that the Gram Sabha Meetings are convened once in each quarter preferably on 26th JanuaryRepublic Day; 1st May-Labour Day; 15th August-Independence Day and 2nd October-Gandhi Jayanti. The Government of India decided to observe the year 1999-2000 as the "Year of Gram Sabha" since it is potentially the most significant institution for participatory and decentralized democracy. Evolving Support Systems On 17th March, 1999, all Chief Ministers/ Administrators have been requested to initiate measures to energise the Gram Sabha in tune with seven point minimal package during the 'Year of Gram Sabha'. It was resolved that the following four-point strategy for strengthening of Gram Sabhas will be implemented by the States:

1) Awareness through print and electronic media, street plays and training to the elected Panchayat representatives.

2) Participation of the community in the preparation of need-based action plans, their execution and monitoring.

3) Transparency information on availability of by displaying all relevant a bill board regarding estimates, funds and expenditure.

\section{CONCLUSION}

There is no doubt that the Gram Sabha has the potential capacity and capability to activate participatory process, it can serve useful purpose in promoting transparency and accountability at local level and if given an opportunity, it can prove to be a gateway for resonating direct democracy at the grass-roots level. It thus, goes without saying that a vibrant Gram Sabha can help in achieving the goals of sustainable rural development through decentralized governance. In addition, it can lubricate the potential of the people for rural development. In order to accelerate the emergence of Gram Sabhas, the powers and functions of Gram Sabha should be spelt out in detail, articulating their role as planners, decision-makers and auditors. Since the Government now stands as a major contributor to PRI funds, it seems appropriate to adopt both the language and methodology of monitoring and evaluation systems in the modern development context, rather than the outdated notions of inspection and supervision. In course of time, PRIs will, doubtless, attract other donor funds, which will be subjected to the same norms of accountability.

\section{REFERENCES}

[1] Number of Districts/DRDAs/Blocks/Villages in India (2000, 2001, 2004, 2005, 2008, 2012)

[2] Selected State-wise Number of Left Wing Extremist (LWE) Affected Districts in India (2009 to 2012-Upto 30.06.2012)

[3] Number of Districts, Increase in Number of Districts and Average Population Size of Districts in India (As per 1961 to 2011 Census)

[4] Number of States, Union Territories, Districts, Tehsils/Sub-Districts, Community Development Blocks, Towns and Villages in India (As per 1991, 2001 and 2011 Census)

[5] State-wise List of 47 New Districts in India (As per 2011 Census)

[6] State-wise List of Districts in India (As per 2011 Census)

[7] State-wise Name of New Districts Created in India (1981-1991, 1991-2001 and 2001-2011)

[8] State-wise Number of District, Sub-Districts, Towns and Villages in India (As per 2011 Census) 
[9] State-wise Number of Districts/New Districts, Affected Districts and Number of Districts with no Jurisdictional Changes in India (As per 2011 Census)

[10] State-wise List of Backward Districts in India (2009-2010)

[11] State-wise List of Border Districts in India (2009-2010)

[12] State-wise List of Left-Wing Extremist Affected (LWE) Districts in India (2009-2010)

[13] State-wise List of Minority Concentrated Districts (MCD) in India (2009-2010)

[14] State-wise List of Scheduled Caste (SC) Concentration Districts in India (2009-2010)

[15] State-wise List of Scheduled Tribe (ST) Concentration Districts in India (2009-2010)

[16] State-wise Number of Districts, Tehsils and Subdivisions Sanctioned and Work Completed under Computerisation of Land Records Programme in India (As on 16.03.2007)

[17] State-wise Number of Districts/DRDAs and Blocks in India (As on 31.01.2004 and 01.11.2005)

[18] State-wise Name of Backward Districts Initiative Plan under Rashtriya Sam Vikas Yojana in India (2002-2003)

[19] State-wise Number of Backward Districts Identified by Task Force in India (2002)

[20] Administrative Division-wise Number of District in India (As per 2001 Census)

[21] List of Districts with New Name in India (As per 2001 Census)

[22] State-wise List of 127 New Districts in India (As per 2001Census)

[23] State-wise List of Districts in India (As per 2001 Census)

[24] State-wise Number of District, Sub-Districts, Towns and Villages in India (As per 2001 Census)

[25] Administrative Division-wise Number of District in India (As per 1991 Census)

[26] Administrative Division-wise Number of District in India (As per 1981 Census)

[27] State-wise Name of New Districts Created in India (1951-1961, 1961-1971 and 1971-1981)

[28] Administrative Division-wise Number of District in India (As per 1971 Census)

[29] Administrative Division-wise Number of District in India (As per 1961 Census)

[30] Administrative Division-wise Number of District in India (As per 1951 Census) 